Подлевська О. М. ${ }^{[1 ;}$ ORCID ID:0000-0003-4979-9282] к.е.н., доцент,

Савіна Н. Б. [1; ORCID ID: 0000-0001-8339-1219], д.е.н., професор,

Подлевський А. А. [1; ORCID ID: 0000-0002-3166-7487], к.е.н., доцент

${ }^{1}$ Національний університет водного господарства та природокористування, м. Рівне

\title{
ПІДПРИЕМНИЦТВО ТА ІНВЕСТИЦІЙНА ДІЯЛЬНІСТЬ В УКРАЇНІ В УМОВАХ КАРАНТИННИХ ОБМЕЖЕНЬ
}

У статті розглянуто вплив пандемії коронавірусу COVID-19 як найбільш вагомого чинника середньо- та довгострокових змін на розвиток підприємництва та інвестиційної діяльності в Україні. Уточнено, що внаслідок запровадження вимушених заходів щодо обмеження окремих видів діяльності у зв'язку із карантином, сектор підприємництва зазнає найбільших збитків, що відіграє вирішальну роль у нагромадженні кризових процесів в економіці, в тому числі, - переддефолтного стану суб'єктів бізнесу. Обґрунтовано, що відсутність адаптивної державної підтримки в Україні може призвести до скорочення майже на третину валової доданої вартості, зайнятості та податкових надходжень від цього сегменту.

Ключові слова: підприємництво; інвестиції; державна підтримка; ризики; світова економіка; реформи.

Вступ. У зв'язку з кризовою ситуацією, викликаною пандемією COVID-19, український бізнес в 2020 р. опинився на межі виживання. Спад економіки, скорочення купівельної спроможності та зміна поведінки громадян, відсутність підтримки (або ії неефективність) 3 боку держави призвели до скорочення виробництва, або навіть зупинки цілих галузей господарства. Збереження карантинних обмежень на здійснення окремих видів економічної діяльності на тлі загального тренду стагнації економіки посилили критичні ризики для національного підприємництва. Різке згортання діяльності малих та середніх підприємств України здатне спричинити руйнівні системні наслідки для національної економіки, призвівши до спаду ВВП та погіршення макроекономічного дисбалансу, дестабілізації банківської системи внаслідок дефолтів суб'єктів підприємництва та фізичних осіб-позичальників, які залишилися без роботи, збільшення безробіття, нарощення дебіторської та кредиторської 
заборгованості. Карантинні заходи загострили проблеми нерівномірного впливу карантину на окремі сегменти підприємництва на національному та місцевому рівнях.

Аналіз останніх досліджень і публікацій. Дослідженню проблем сучасного стану та розвитку підприємництва та інвестиційної діяльності в Україні, характерних рис формування середовища бізнесу, державної політики підтримки малого підприємництва та стратегій його розвитку в Україні присвятили свої роботи такі українські науковці, як 3. С. Варналій [4, С. 104; 7, С. 226], С. Попов [5, С. 3-5], В. В. Виговська [6, С. 59-63], В. М. Геєць [7, С. 226], С. Г. Дрига [8, С. 459], В. В. Папп [9, С. 160-164], Т. А. Піхняк [10, C. 270-274] та ін. Під впливом зовнішніх та внутрішніх факторів, спричинених карантином, філософія та умови ведення бізнесу в значній мірі трансформуються, а бізнес-сектор потребує виваженої державної підтримки, що актуалізує необхідність проведення відповідних досліджень.

Постановка завдання. Мета дослідження - визначення пріоритетів розвитку та підтримки підприємництва та інвестиційної діяльності в Україні для прискорення відновлення в умовах коронакризи.

Викладення основного матеріалу. Пандемія COVID-19 спричинила серйозні збої у світовій економіці. На економічну діяльність вплинуло зменшення особистої взаємодії як через офіційні обмеження, так і через приватні рішення; певна невизначеність щодо постпандемічної економічної ситуації та політики стримувала інвестиції; зриви в освіті сповільнили накопичення та розвиток людського потенціалу; нестабільність щодо глобальних ланцюгів створення вартості та перебігу пандемії вплинули на міжнародну торгівлю та туризм.

Висновки економістів Європейського банку реконструкції та розвитку, які досліджували наслідки коронакризи для країн, якими опікується банк, - від Монголії та Росії до Центральної Європи і Балкан та Туреччини і Марокко, є доволі невтішними, і Україна не $є$ винятком. Українська економіка почала падати ще до карантину, а під час нього це падіння суттєво пришвидшилося. Економічне падіння, із якими через коронавірус стикнулися країни євразійського регіону й Україна зокрема, виявилося крутішим, ніж оцінювали раніше. Це пов'язано із тим, що перша половина року насправді виявилася важчою, ніж очікувалося, а карантинні обмеження повністю так і не зняли.

Внаслідок пандемії коронавірусу та введених карантинних 
заходів падіння українського ВВП за даними Міністерства розвитку економіки, торгівлі та сільського господарства першій половині 2020 р. склало 6,5\%. За прогнозом Національного банку України (НБУ) падіння ВВП у 2020 року може скласти мінімум 6\%. Водночас, за оцінкою МВФ, українська економіка зменшиться за підсумками 2020 року на $8,2 \%$ [2].

Карантин понизив споживчі настрої, майже зупинив декілька галузей - роздрібну торгівлю, готельний та ресторанний бізнес, авіаперевезення, що не могло не позначитися на зменшення обсягів надходжень до бюджету (рис. 1).

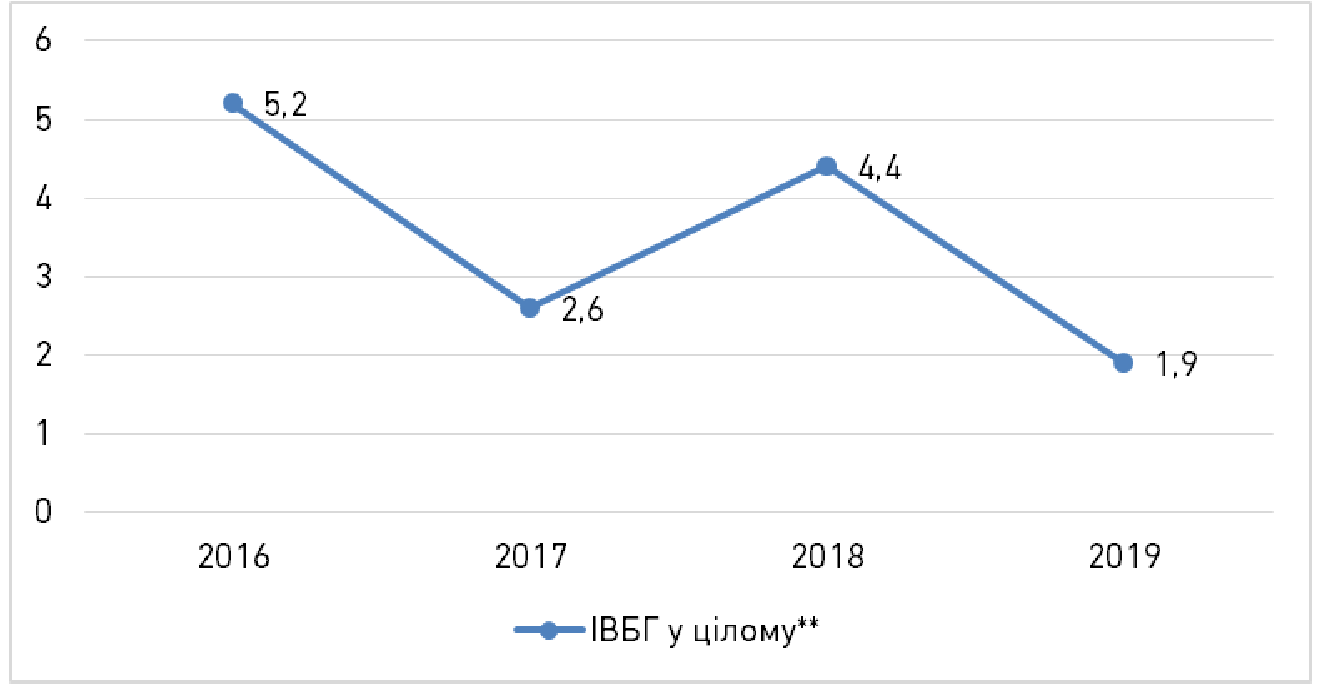

Рис. 1. Динаміка індексу виробництва базових галузей, \%

Внаслідок введення карантину багато українських компаній заморозили інвестиції та виробничі ланцюжки. Тим не менш, сектори, які пов'язані із споживчим попитом і де відбувається послаблення карантинних обмежень, доволі швидко відновлюються. Насамперед, це стосується сфери роздрібної торгівлі та послуг.

Набагато складніша ситуація із промисловістю та інвестиційним попитом, що відображає рис. 2. 


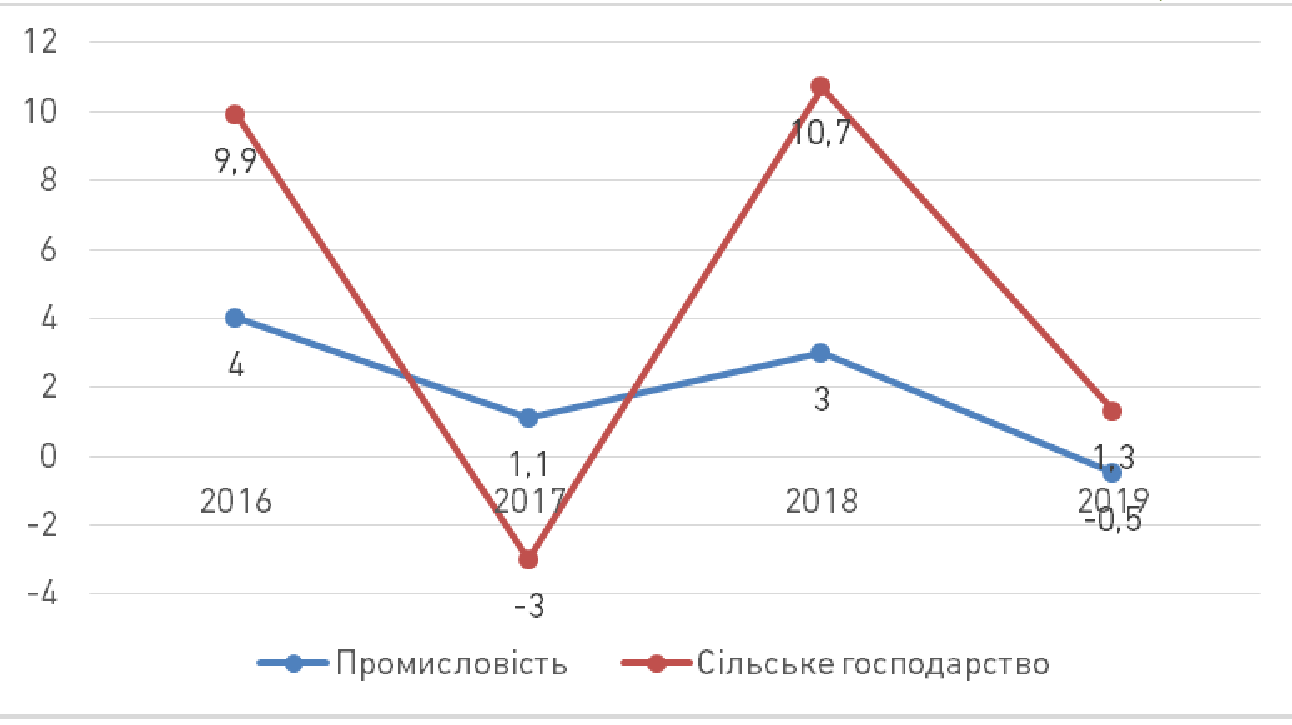

Рис. 2. Динаміка індексу промисловості та сільського господарства, \%

Відновлення промисловості відбувається повільніше, ніж роздрібної торгівлі. Воно дуже нерівномірне - вплив карантину для одних галузей був більш болючим ніж для інших.

Спалах пандемії коронавірусу спричинив падіння світової економіки, обсягів торгівлі та цін на товари, відплив капіталу з нових ринкових економік. Завдяки масштабним стимулюючим заходам ціни активів і товарів частково «відіграли» падіння. Відновлення глобальної економіки очікується в другому півріччі, проте для цього сценарію $\epsilon$ низка загроз. За оцінками Світового банку [11], глобальний ВВП впаде цього року найбільше з часів Другої світової війни - на 5,2\%. Ризики подальшого погіршення прогнозів високі. Світовий банк очікує глибокого падіння майже всіх основних торговельних партнерів України. Економіка Китаю, який першим запровадив обмеження, різко сповільнить зростання. Скорочення економічної активності найбільше торкнулося туризму, пасажирських та авіаперевезень, громадського харчування; їхні перспективи $€$ непевними (рис. 3).

За першу половину 2020 року товарообіг України склав $\$ 47,3$ млрд. В Україну імпортували товарів на понад $\$ 24,3$ млрд (у порівнянні 3 першим півріччям 2019 р. імпорт зменшився на $\$ 3,4$ млрд або на 12\%). Експортували з України на \$23 млрд (зменшення експорту склало \$1,6 млрд або на 6\%). Відповідно, сальдо (різниця між імпортом та експортом) - від'ємне - \$1,4 млрд [11]. Найбільше імпортували з Китаю - 15\% від загального імпорту, 
Німеччини - 9\% та Російської Федерації - 9\%. Головні партнери 3 експорту Китай - 13\% від загального експорту, Польща - 6\% та Російська Федерація - 6\% [1].

Скорочення обсягів світової торгівлі у 2020 році, за прогнозами СОТ, становитиме від $13 \%$ до $32 \%$ залежно від сценарію розвитку подій, що суттєвіше за падіння світового ВВП. Відновлення обсягів торгівлі у 2021 році є непевним. Від березня 2020 р. міжнародні інвестори втратили інтерес до нових ринкових економік. Приплив прямих іноземних інвестиції в Україну у березні-квітні також припинився, а чистий відплив портфельних інвестицій становив 0,85 млрд дол. США [3]. Відплив капіталу був зумовлений бажанням інвесторів збільшити вкладення в безпечні інструменти, а також падінням цін на сировинні ресурси.

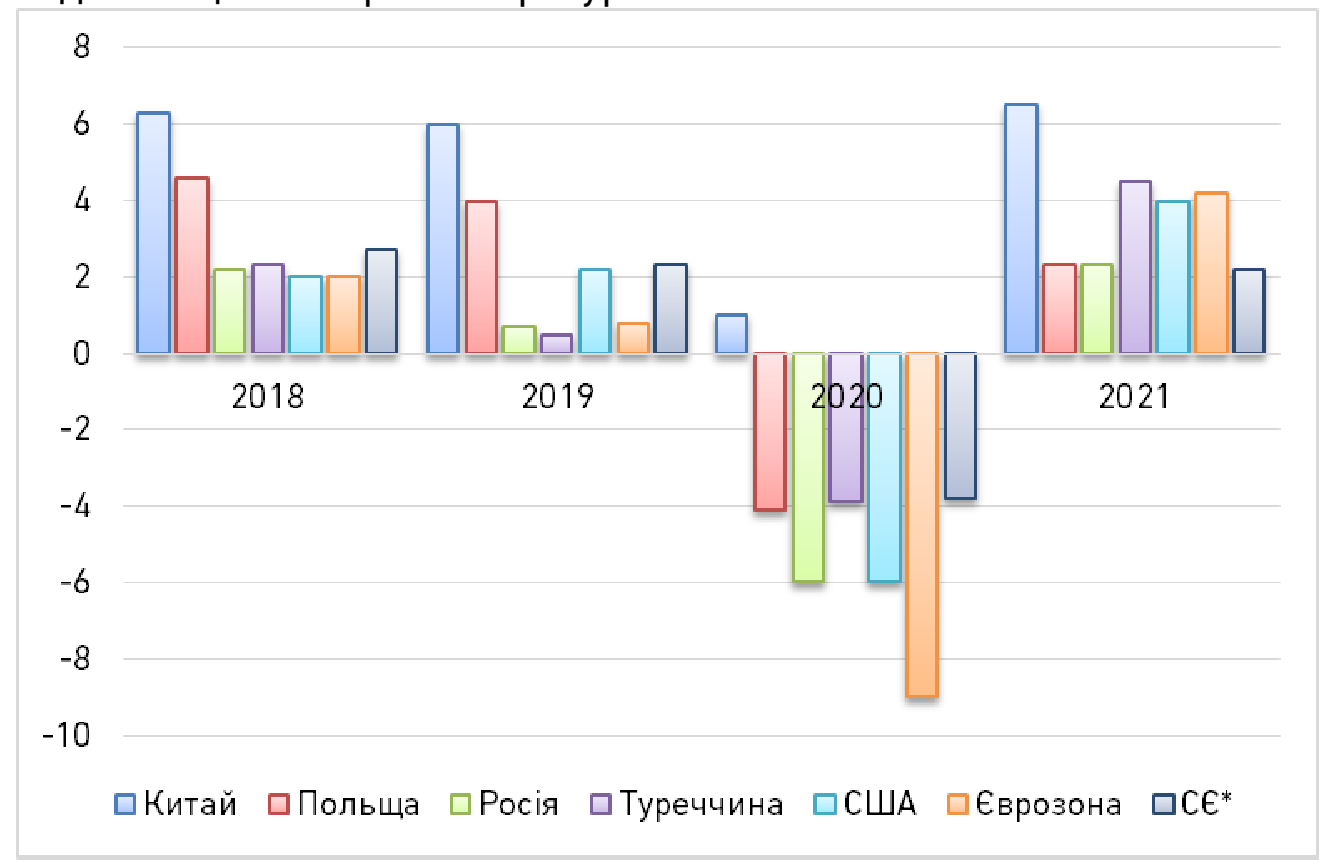

Рис. 3. Динаміка ВВП країн-основних торговельних партнерів України, \% [11]

${ }^{*}$ Східна Європа: Білорусь, Україна, Молдова

Україна увійшла в поточну економічну кризу зі збалансованою макроекономічною ситуацією. Відносно низький рівень захворюваності на COVID-19 у більшості регіонів дав змогу поступово знімати карантинні обмеження. Завдяки подальшому послабленню інфляційного тиску НБУ швидше пом'якшував монетарну політику та заклав передумови для відчутного зниження вартості кредитів. Однак масштаби зниження економічної активності у 2020 році будуть 
значними, а відновлення може зайняти більше часу, ніж передбачалося раніше [3].

Серед головних ризиків для світової економіки, та економіки України зокрема, варто виділити наступні:

1. Необхідність посилення заходів обмеження через нові хвилі вірусу може призвести до повторної деформації глобальних виробничих зав'язків, а саме - до суттєвого зниження попиту у країнах, що є торговельними партнерами України.

2. У відповідності до першого пункту, за умови призупинення торговельних потоків та виробничих потужностей виникає загроза щодо накопичення запасів та перенасичення світового ринку товарами, внаслідок цього - можливе стрімке падіння цін на світових товарних ринках.

3. Очікування погіршення світової економіки призведе до перерозподілу капіталів у ті країни, які мають більш стійкіше макрофінансове середовище та виявили достатній рівень проведення структурних реформ, як наслідок - відплив капіталу 3 тих країн, ринки яких ще розвиваються.

Серед основних ризиків також варто відмітити припинення співпраці з МВФ, згортання структурних реформ та тривалішій термін пандемії коронавірусу зі збереженням обмежувальних заходів на більш довшій період. Саме від цього буде залежати швидкість відновлення як світової так і української економіки зокрема. Також варто зазначити актуальність ризиків, пов'язаних із зниженням урожайності внаслідок несприятливих кліматичних умов та ескалації військово конфлікту на сході країни.

Прогнози на найближчі перспективи залишаються вкрай невизначеними, і в області зростання економіки, як і раніше, можливі різні сценарії. При песимістичному сценарії, який передбачає продовження зростання захворюваності і затримки 3 впровадженням вакцини, зростання світової економіки в 2021 році може бути обмежений до 1,6\% [12]. При оптимістичному сценарії, який передбачає успішне приборкання пандемії і прискорення процесу вакцинації, темпи економічного зростання в світі можуть підвищитися майже до 5 відсотків. Пожвавлення, яке почалося в країнах з розвиненою економікою, загальмувалося в третьому кварталі 2020 р. після нового сплеску захворюваності - це свідчить про те, що відновлення економіки буде повільним і непростим.

Після скорочення в 2020 році, що склало, за оцінками, 3,6\%, в 2021 році ВВП США виросте, згідно з прогнозами, на 3,5\%. Обсяг виробництва в зоні євро, як очікується, виросте в 2021 році на 3,6\% після скорочення на 7,4\% в 2020 році. В Японії, де в минулому році 
спостерігався спад на 5,3\%, в 2021 році прогнозується зростання економічної активності на 2,5\%. Очікується, що сукупний ВВП країн 3 ринком, що формується і країн, що розвиваються, включаючи Китай, виросте в 2021 році на 5\% після скорочення на 2,6\% в 2020 році. Передбачається, що економіку Китаю, що виросла в минулому році на 2\%, в цьому році чекає зростання на 7,9\%. Зростання економіки країн з ринком, що формується і країн, що розвиваються, за винятком Китаю, за прогнозами, складе в 2021 році 3,4\%, після зниження на 5\% в 2020 році. Прогнозується, що в країнах з низьким рівнем доходу економічна активність в 2021 році підвищиться на 3,3\%, тоді як в 2020 році спостерігався спад на 0,9\% [12].

«Пандемія значно погіршила боргові ризики в країнах 3 ринком, що формується і країнах, що розвиваються; слабкість перспектив економічного зростання, швидше за все, призведе до подальшого зростання тягаря заборгованості і знизить здатність позичальників обслуговувати заборгованість» - попередив виконуючий обов'язки віцепрезидента Світового банку 3 питань справедливого росту і фінансових установ Айхан Косі. «Світовій спільноті необхідно вжити швидких і рішучих заходів, щоб не допустити виникнення низки боргових криз в результаті недавнього накопичення заборгованості. Країни, що розвиваються не можуть дозволити собі ще одне втрачене десятиліття» [12].

Можна очікувати, що ця пандемія, подібно до інших серйозних криз минулого, надасть тривалий негативний вплив на економічну активність у світі. Швидше за все, вона посилить уповільнення темпів зростання світової економіки, прогнозоване на майбутнє десятиліття і обумовлене недоінвестуванням, неповною зайнятістю і скороченням робочої сили в багатьох країнах 3 розвиненою економікою.

Як підказує історичний досвід, світовій економіці належить десятиліття негативних показників економічного зростання - якщо центральні органи не здійснять швидких комплексних реформ, спрямованих на підвищення ефективності основоположних чинників рівноправного і стійкого економічного зростання. Центральним органам необхідно докладати подальших зусиль до забезпечення стійкості відновлення, здійснюючи поступовий перехід від політики підтримки доходів до політики сприяння економічному зростанню. У більш довгостроковій перспективі заходи політики, спрямовані на поліпшення послуг охорони здоров'я та освіти, вдосконалення цифрової інфраструктури, підвищення стійкості до зміни клімату, підвищення ефективності практичних рішень в області підприємницької діяльності та управління, допоможуть пом'якшити 
економічний збиток, нанесений пандемією, скоротити масштаби бідності та прискорити забезпечення загального добробуту в країнах з ринком, що формується і країнах, що розвиваються. Інституційні реформи, спрямовані на стимулювання органічного зростання економіки, мають особливо велике значення на тлі складного становища в фінансово-бюджетній сфері та зростання заборгованості. У минулому віддача від реформ у вигляді активізації економічного зростання спонукала інвесторів переглядати свої довгострокові прогнози зростання економіки і нарощувати інвестиції.

1. Державна служба статистики України : вебсайт. URL: http://www.ukrstat.gov.ua. (дата звернення: 15.12.2020). 2. Економічна правда : вебсайт. URL: https://www.epravda.com.ua/news/ (дата звернення: 15.12.2020). 3. Вплив COVID19 та карантинних обмежень на економіку України. Кабінетне дослідження. Липень 2020 : вебсайт. URL: https://www.kas.de/documents/270026/8703904 (дата звернення: 15.12.2020). 4. Варналій 3. С. Мале підприємництво: основи теорії $\mathrm{i}$ практики. 4-те вид., стер. Київ : Знання, КОО, 2008. 302 с. 5. Попов С., ПоліщукГ. Забезпечення ефективності державної політики підтримки розвитку малого підприємництва: окремі аспекти. Інформаційний простір. Українські реалії: досвід трансформацій : матеріали V Міжнар. наук.-практ. конф. Хелм, Польща, 2016. С. 3-5. 6. Виговська В.В. Малий бізнес України: сучасний стан і тенденції розвитку. Актуальні проблеми економіки. 2009. № 1. С. 59-63. 7. Про стан та перспективи розвитку підприємництва в Україні / Варналій 3. С., Геєць В. М., Кужель О. М., Лібанова Е.М. та ін. Національна доповідь / за ред. В. М. Гейця. Київ : Держкомпідприємництво, 2008. 226 с. 8. Дрига С. Г. Мале підприємництво України: становлення, механізми управління та підтримки : монографія. Київ : ТОВ «ДКС центр», 2009. 459 с. 9. Папп В.В. Сучасний стан і тенденції розвитку малого підприємництва в Україні. Бізнес Інформ. 2013. №6. С. 160-164. 10. Піхняк Т. А. Організаційно-економічний механізм державного управління підприємствами малого бізнесу: світовий досвід та уроки для України. Науковий вісник НЛту України : зб. наук.-техн. праць. 2012. Вип. 22.2. С. 270-274. 11. The World Bank. Global Economic Prospects. The World Bank. June 2020. URL: https://www.worldbank.org/en/publication/globaleconomic-prospects

(accessed: 15.12.2020). 12. Global Economic Prospects. International Bank for Reconstruction and Development. The World Bank. January 2021. URL: https://www.worldbank.org/en/publication/global-economic-prospects (accessed: 15.12.2020).

\section{REFERENCES:}

1. Derzhavna sluzhba statystyky Ukrainy : vebsait. URL: http://www.ukrstat.gov.ua. (data zvernennia: 15.12.2020). 2. Ekonomichna pravda : vebsait. URL: https://www.epravda.com.ua/news/ (data zvernennia: 15.12.2020). 3. Vplyv COVID-19 ta karantynnykh obmezhen na ekonomiku Ukrainy. Kabinetne doslidzhennia. Lypen 2020 : vebsait. URL: https://www.kas.de/documents/270026/8703904 (data zvernennia: 15.12.2020). 4. Varnalii Z. S. Male pidpryiemnytstvo: osnovy teorii i praktyky. 4-te vyd., ster. Kyiv : Znannia, KOO, 2008. 302 s. 5. Popov S., Polishchuk H. 
Серія «Економічні науки»

Випуск 4(92) 2020 p.

Zabezpechennia efektyvnosti derzhavnoi polityky pidtrymky rozvytku maloho pidpryiemnytstva: okremi aspekty. Informatsiinyi prostir. Ukrainski realii: dosvid transformatsii : materialy V Mizhnar. nauk.-prakt. konf. Khelm, Polshcha, 2016. S. 3-5. 6. Vyhovska V. V. Malyi biznes Ukrainy: suchasnyi stan i tendentsii rozvytku. Aktualni problemy ekonomiky. 2009. № 1. S. 59-63. 7. Pro stan ta perspektyvy rozvytku pidpryiemnytstva v Ukraini / Varnalii Z. S., Heiets V. M., Kuzhel O. M., Libanova E. M. ta in. Natsionalna dopovid / za red. V. M. Heitsia. Kyiv : Derzhkompidpryiemnytstvo, 2008. 226 s. 8. Dryha S. H. Male pidpryiemnytstvo Ukrainy: stanovlennia, mekhanizmy upravlinnia ta pidtrymky : monohrafiia. Kyiv : TOV «DKS tsentr», 2009. $459 \mathrm{~s}$. 9. Papp V. V. Suchasnyi stan i tendentsii rozvytku maloho pidpryiemnytstva v Ukraini. Biznes Inform. 2013. № 6. S. 160-164. 10. Pikhniak T. A. Orhanizatsiino-ekonomichnyi mekhanizm derzhavnoho upravlinnia pidpryiemstvamy maloho biznesu: svitovyi dosvid ta uroky dlia Ukrainy. Naukovyi visnyk NLTU Ukrainy : zb. nauk.-tekhn. prats. 2012. Vyp. 22.2. S. 270-274. 11. The World Bank. Global Economic Prospects. The World Bank. June $2020 . \quad$ URL https://www.worldbank.org/en/publication/globaleconomic-prospects (accessed: 15.12.2020). 12. Global Economic Prospects. International Bank for Reconstruction and Development. The World Bank. January 2021. URL : https://www.worldbank.org/en/publication/global-economic-prospects (accessed: 15.12.2020).

Podlevska O. M. [1; ORCID ID:0000-0003-4979-9282], Candidate of Economics (Ph.D.), Associate Professor Savina N. B. [1; ORCID ID: 0000-0001-8339-1219], Doctor of Economics, Professor, Podlevskyi A. A. ${ }^{[1 ;}$ ORCID ID: 0000-0002-3166-7487] Candidate of Economics (Ph.D.), Associate Professor

${ }^{1}$ National University of Water and Environmental Engineering, Rivne

\section{ENTREPRENEURSHIP AND INVESTMENT ACTIVITIES IN UKRAINE UNDER QUARANTINE RESTRICTIONS}

The article considers the impact of the COVID-19 coronavirus pandemic as the most important factor of medium- and long-term changes on the development of entrepreneurship and investment activity not only in Ukraine but also in the world.

It is clarified that due to the introduction of forced measures to limit certain activities in connection with quarantine, the business sector suffers the greatest losses, which plays a crucial role in the accumulation of crisis processes in the economy, including the pre-default state of business entities. As a result of quarantine, many Ukrainian companies have frozen investments and production chains, however, sectors that are related to consumer demand (retail and services) are recovering fairly quickly.

The outbreak of the coronavirus pandemic caused the fall of the world 
economy, trade and commodity prices, and the outflow of capital from new market economies. The World Bank expects a deep decline in almost all of Ukraine's major trading partners, which could negatively affect the domestic economy. Investment, in particular, collapsed in 2020 in many emerging market and developing economies, following a decade of persistent weakness. Investment growth is expected to resume in 2021, but, despite an uplift from advances in digital technology, not add enough to reverse the large $\mathbf{2 0 2 0}$ decline. The experience of past crises raises a further concern without urgent course correction, investment could remain feeble for years to come.

It was found that Ukraine has entered the current economic crisis with a balanced macroeconomic situation. The relatively low incidence of COVID19 in most regions has made it possible to gradually lift quarantine restrictions, but the scale of the decline in economic activity in 2020 is already significant. The main risks to Ukraine's economy have been identified, including the cessation of cooperation with the IMF, the curtailment of structural reforms, and the prolongation of the coronavirus pandemic, while maintaining restrictive measures for a longer period.

It is substantiated that the lack of adaptive state support in Ukraine may lead to a reduction of almost a third of gross value added, employment and tax revenues from this segment.

Keywords: entrepreneurship; investment; government support; risks; world economy; reforms.

Подлевская О. М. ${ }^{[1 ;}$ ORCID ID:0000-0003-4979-9282] к.э.н., доцент,

Савина Н. Б. [1; ORCID ID: 0000-0001-8339-1219], д.э.н., професор

Подлевский А. А. [1; ORCID ID: 0000-0002-3166-7487], к.э.н., доцент

${ }^{1}$ Национальный университет водного хозяйства и природопользования, г. Ровно

\section{ПРЕДПРИНИМАТЕЛЬСТВО И ИНВЕСТИЦИОННАЯ ДЕЯТЕЛЬНОСТЬ В УКРАИНЕ В УСЛОВИЯХ КАРАНТИННЫХ ОГРАНИЧЕНИЙ}

В статье рассмотрено влияние пандемии коронавируса COVID-19, как наиболее весомого фактора средне- и долгосрочных изменений на развитие предпринимательства и инвестиционной деятельности В Украине. Уточнено, что в результате введения вынужденных мер по ограничению отдельных видов деятельности в связи с карантином, сектор предпринимательства испытывает наибольшие убытки, что 
играет решающую роль в накоплении кризисных процессов в экономике, в том числе - переддефолтного состояния субъектов бизнеса. Обосновано, что отсутствие адаптивной государственной поддержки в Украине может привести к сокращению почти на треть валовой добавленной стоимости, занятости и налоговых поступлений от этого сегмента.

Ключевые слова: предпринимательство; инвестиции; государственная поддержка; риски; мировая экономика; реформы.

Стаття надійшла до редакції 16.12.2020 р. 